\title{
Design of Flying Capacitor Multilevel Inverter for Solar Energy Applications
}

\author{
Nitin Pawar ${ }^{1}$, Vijay Kumar Tayal ${ }^{1}$ and Pallavi Choudekar ${ }^{1}$ \\ ${ }^{1}$ Amity University, Noida, Uttar Pradesh, India
}

\begin{abstract}
The continuous rise in electricity demand leads to adoption of renewable energy sources such as sun, wind for power generation. In order to utilize the electric power obtained from renewable solar energy, inverters are required to inject the electricity into the grid. This paper presents single phase flying capacitor multi-level inverter with help of SPWM technique. The comparison of single phase three-level, five-level and seven-level flying capacitor multilevel inverters is carried out with respect to waveform pattern, output current, output voltage, active power and reactive power waveforms. The simulations are conducted in MATLAB/SIMULINK environment.
\end{abstract}

\section{Introduction}

In order to get better utilization of renewable energy sources [1-2] the electricity generated is to be connected with the grid. The DC power obtained from solar photovoltaic panels is to be inverted into $\mathrm{AC}$ at $50 \mathrm{~Hz}$ frequency with constant voltage matched with the grid voltage [3-6]. The power should be harmonics free and sinusoidal. This requires $\mathrm{DC}$ to $\mathrm{AC}$ multilevel inverters [7-8]. These inverters offer low interference, with high efficiency. In literature various control strategies such as cascaded inverter, hysteresis current control etc have been proposed [9-10].

The multi-level inverter is a system or device which utilizes various low level dc voltages as an input to achie ve optimalalternating voltage at the output. It consists of many switches and arrangement of switches are very important. A multilevel inverter enables higher voltages with less noise at output. It is required to obtain higher output power from sources like battery and solar arrays. Types of inverters are: Cascaded H-bridge inverter (CHB), Flying capacitor inverter (FC) and Diode clamped inverter. In this work, various topologies of flying capacitor inverter and their performances has been compared [11]. The section 2 presents Flying capacitor multilevel inverter and Sinusoidal Pulse Width Modulation (PWM) schemes, modelling of FC inverter is presented in section 3, simulation results are elaborated in section 4 followed by conclusion at the end.

\section{Multilevel Inverter}

The Multi-level inverter can be classified on basis of source i.e. common DC source and separate DC source inverter. Common dc source inverter includes FC and diode clamped inverter. Separate DC source includes
CHB inverter. In CHB, arrangement of switches together with voltage is termed as $\mathrm{H}$-bridge cell. H-bridge cell supply three separate voltages such as $0,+v e$ DC and -ve DC voltages. Each H-bridge cell has a different dc source in this inverter, which requires a wide range of sources and hence its applications is limited. In FC inverter topology condenser are used.

\subsection{Flying Capacitor Multilevel Inverter}

In this type of multilevel inverter topology capacitors are used. The condensers send the restricted amount of voltage to electrical equipment. Switching states of FC inverter and diode clamped inverter are identical [12]. In this form of inverter, clamping diodes are not used. The peak voltage that can be achieve from this inverter cannot greater than half the input voltage. The active and reactive power flow may also be regulated by FC inverter. Switching losses are attributed to the high frequency switching in this form of inverter [13-14].

\section{Sinusoidal Pulse Width Modulation (PWM)}

In this technique sinusoidal signal for PWM is used. With help of this technique gating signal for the inverter switches can be produced by comparing a sinusoidal reference wave with triangle carrier wave and width of each wave which varies according to amplitude of sine wave measured in middle of same wave [15-18].

\section{Modelling of FC Inverter}

In this type of multilevel inverter topology capacitors are used. The 3-level, 5-level and 7-level FC inverter models are shown in Fig. 1-3 respectively. The maximum voltage 
obtained from it cannot be more than half of input voltage. Power Flow can be controlled by capacitor. Switching losses will take place in this type of inverter due to high frequency switching.
In multilevel inverter the output voltage is generated at high frequency and there is low switching frequency with low distortions. Hybrid multi-level inverter is utilised to produce high voltage at output which decreased THD, $\mathrm{dv} / \mathrm{dt}$ stress and common mode voltage.

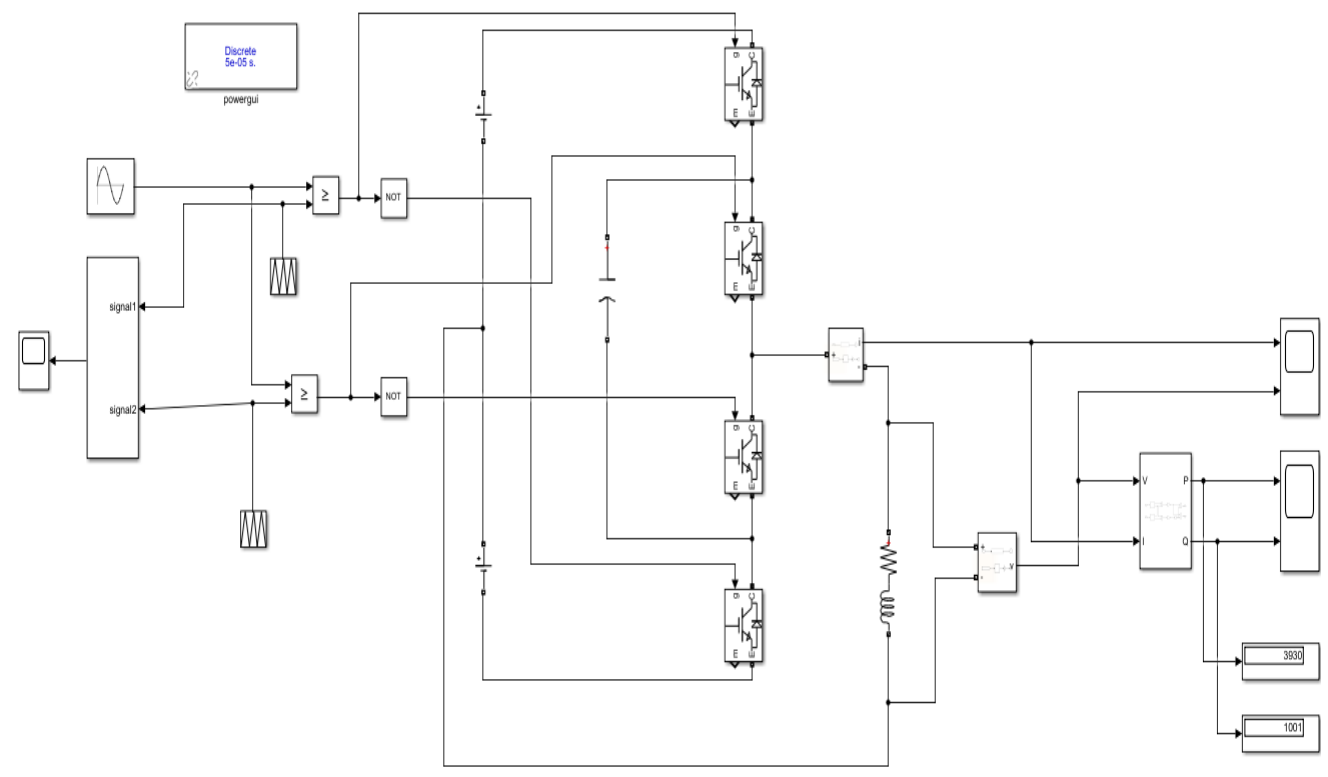

Fig. 1: 3-level FC inverter model

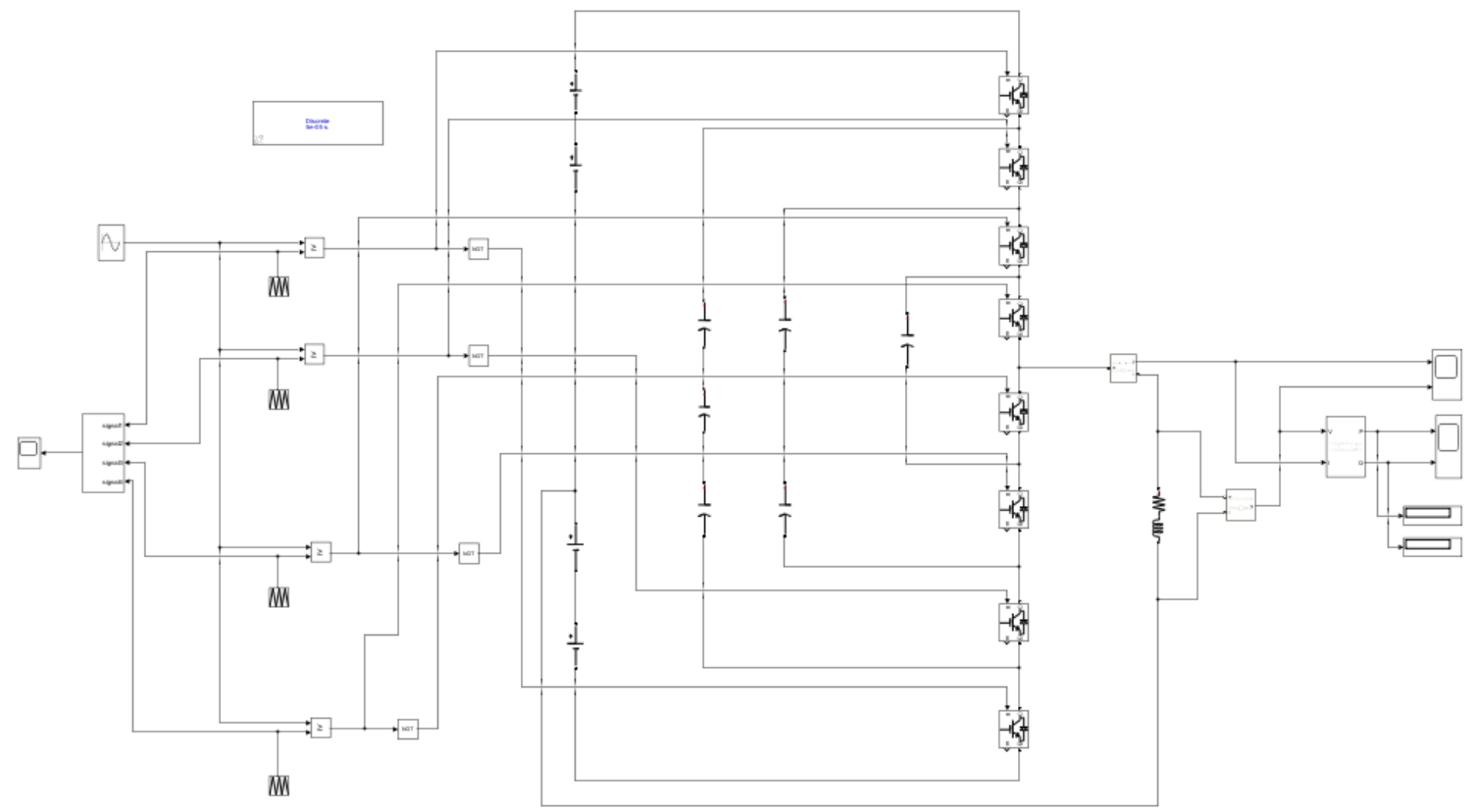

Fig. 2: 5-level FC inverter model 


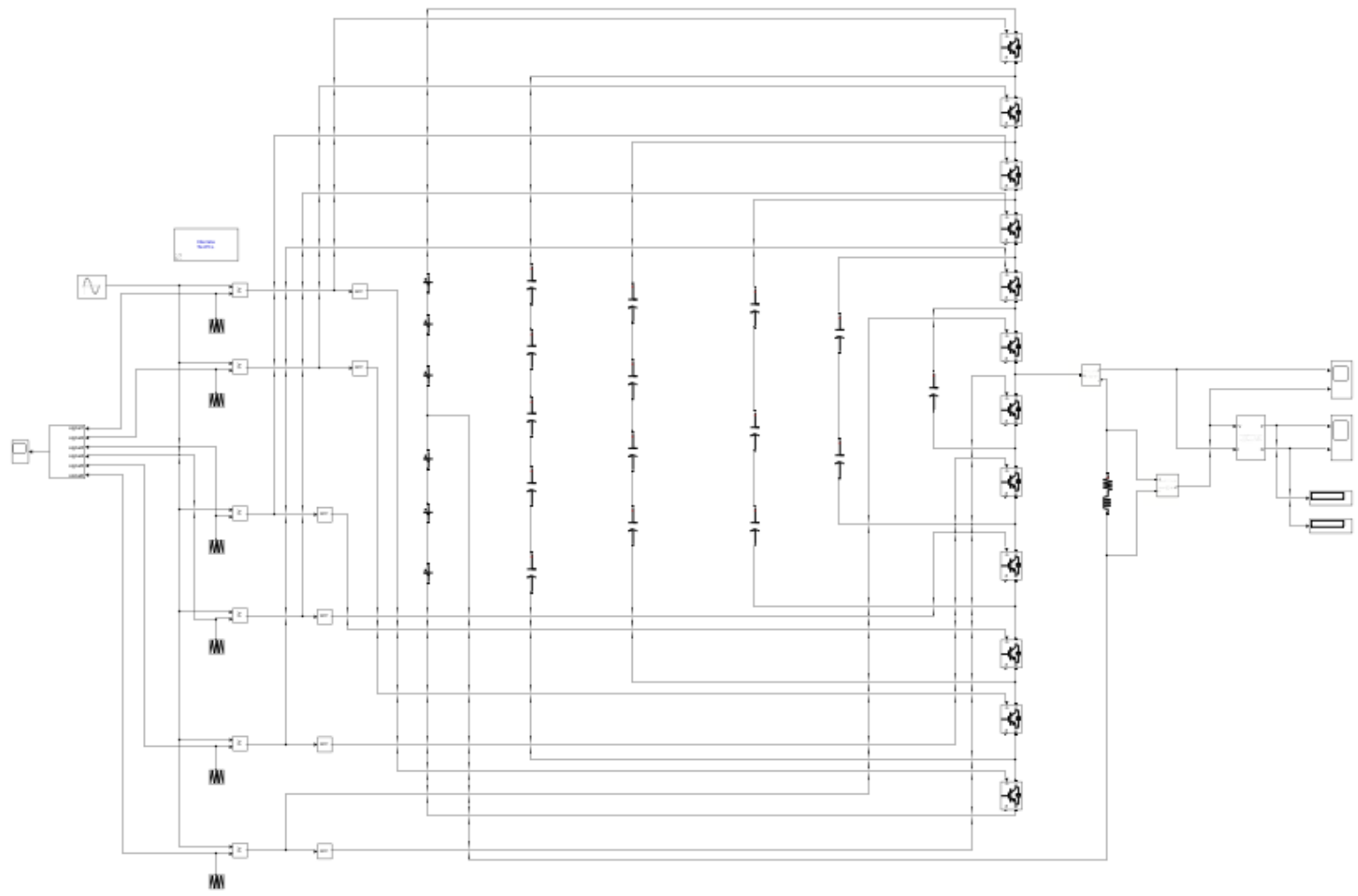

Fig. 3: 7-level FC inverter model

\section{Simulation Results}

In this work, single phase 3-Level, 5-Level and 7-Level FC Inverter schemes with RL-load are considered. The simulations are conducted in Matlab. The output voltage, current, active and reactive powers are depicted in Fig. 412 respectively.

In single phase 3 level FC inverter, inductive load is connected at output and current lags the inductive voltage. RMS value of current and voltage waveform are 33.07 A and $195.5 \mathrm{~V}$ respectively. Active and reactive power waveform value is $3930 \mathrm{~W}$ and 1001 VAR respectively. The PF of load is 0.607 and phase angle is 52.564 degree.

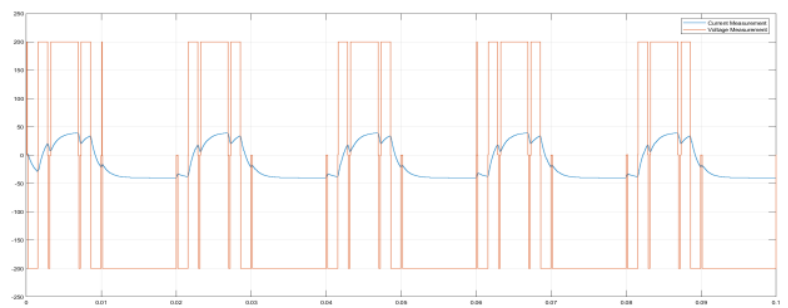

Fig. 4: Output voltage and current waveform of 3-level FC inverter

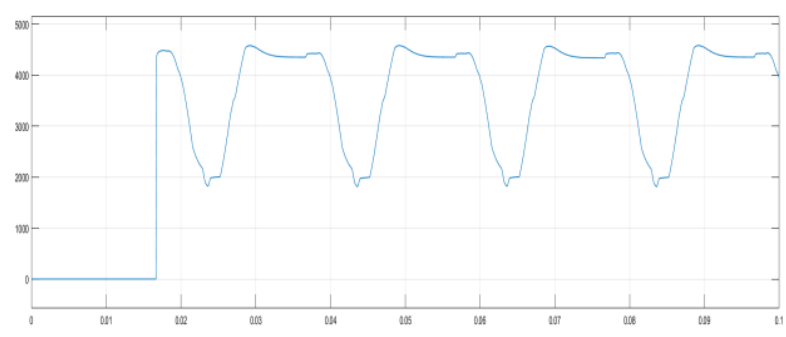

Fig. 5: Active power waveform of 3-level FC inverter

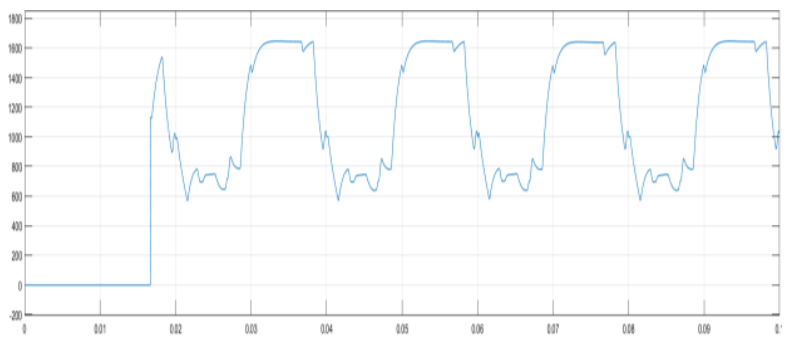

Fig. 6: Reactive power waveform of 3-level FC inverter

Fig. 4-6: Reactive power waveform of 3-level FC inverter- Output voltage and current waveform, Active Power and Reactive Power 


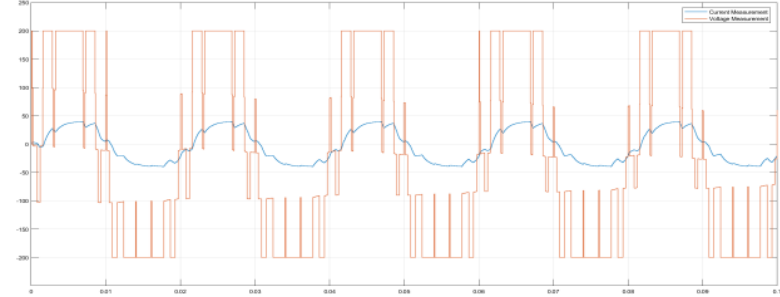

Fig. 7: Output voltage and current waveform of 5-level FC inverter

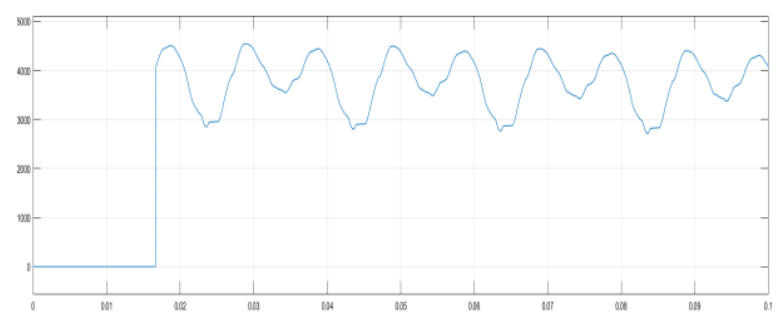

Fig. 8: Active power waveform of 5-Level FC inverter

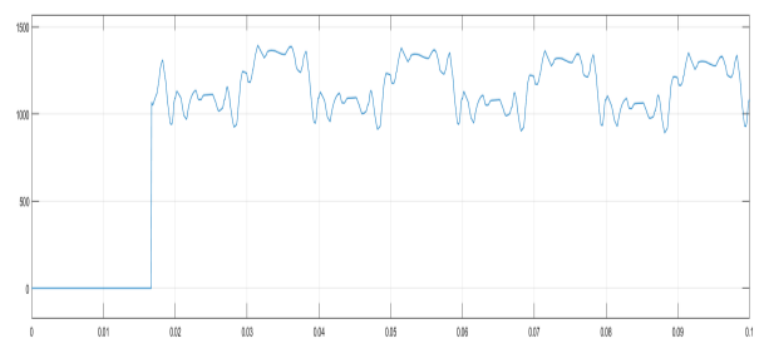

Fig. 9: Reactive power waveform of 5-level FC Inverter

Fig. 7-9: Reactive power waveform of 3-level FC inverter- Output voltage and current waveform, Active Power and Reactive Power.

In single phase 5 level FC inverter, inductive load is connected at output and current lags inductive voltage. The rms value of current and voltage waveform are 29.12 $\mathrm{A}$ and $164.1 \mathrm{~V}$ respectively. Active and reactive power waveform value is $4065 \mathrm{~W}$ and 1075 VAR respectively. The PF of load is 0.850 and phase angle is 31.715 degree.

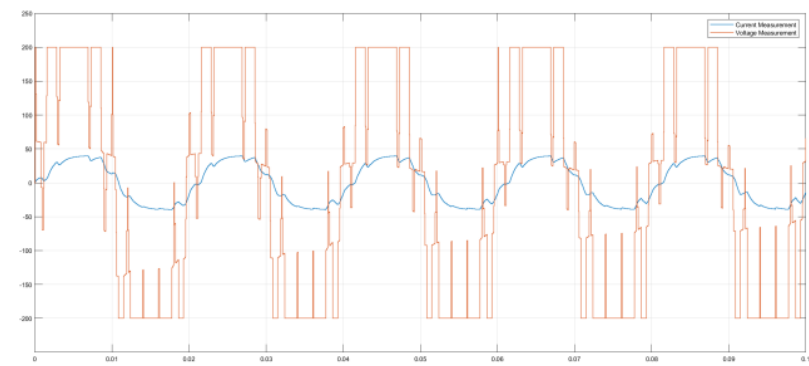

Fig. 10: Output voltage and current waveform of 7-level FC inverter

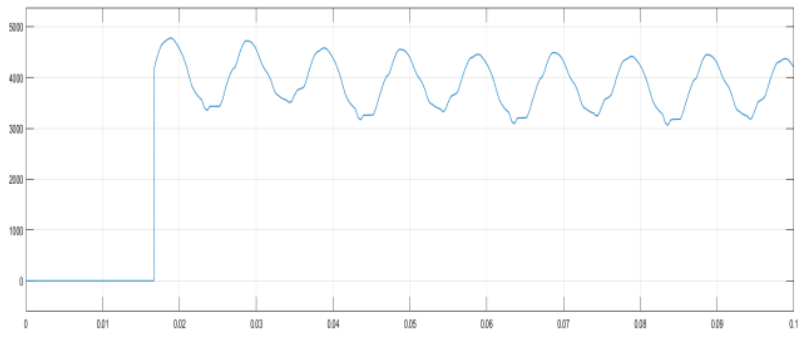

Fig. 11: Active power waveform of 7-Level FC inverter

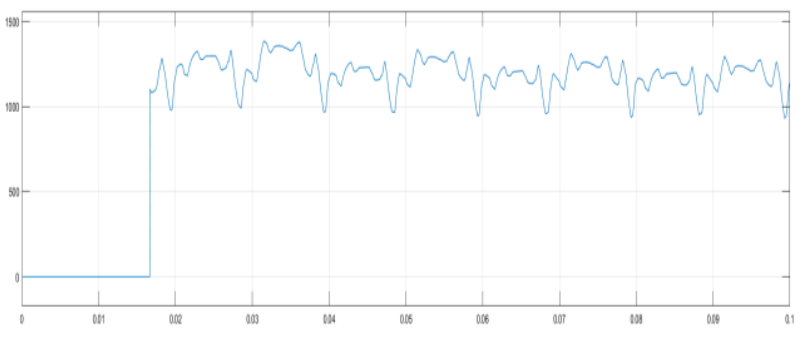

Fig. 12: Reactive power waveform of 7-Level FC inverter

Fig. 10-12: Reactive power waveform of 3-level FC inverter- Output voltage and current waveform, Active Power and Reactive Power

In single phase 7 level FC inverter, inductive load is connected at output and current lags inductive voltage. RMS value of current and voltage waveform are $29.30 \mathrm{~A}$ and $163.3 \mathrm{~V}$ respectively. Active power and reactive power waveform value is $4197 \mathrm{~W}$ and 1139 VAR respectively. The PF of load is 0.877 and phase angle is 28.69 degree.

Thus, higher levels of multilevel inverter show better performance as compared to lower levels of multilevel inverters and noise in the output side of inverter is decrease with increase in levels of multilevel inverter.

\section{Conclusion}

Due to depleting conventional energy sources the use of renewable energy sources is increasing day by day. However, the power produced by solar and wind energy sources is to be connected with the power grid to improve its utilization. This requires harmonics free power with constant voltage and frequency matched with the grid supply. Thus there is a need for suitable power electronic inverters. In this paper, by using the SPWM technique, the single phase three level, five level and seven flying capacitor multilevel inverter are simulated. It is observed that higher levels of flying capacitor multilevel inverter show better performance as compared to lower levels of multilevel inverters It is also observed that noise at output side is decrease with increase in levels of FC inverter, hence it is concluded that for dc to ac conversion for renewable energy applications higher level flying capacitor multilevel inverter should be preferred. 


\section{References}

1. Vasudha Sharma and Vijay Kumar Tayal, "Hardware Implementation of Sun Tracking Solar Panel Using 8051 Micro-Controller", International Conference on Reliability, Infocom Technologies and. Optimization (ICRITO). pp. 483-486 (2017).

2. Yogita Dwivedi and Vijay Kumar Tayal, "Dynamic stability Improvement of Alkali Fuel Cell Integrated System using PSO optimized PID Control Design”, IEEE International Conference on Recent Developments, Control, Automation and Power Engineering (RDCAPE), pp. 499-505 (2017).

3. O. Alonso, P. Sanchis, E. Gubia, L. Marroyo, "Cascaded H-bridge Multilevel Converter for Grid Connected Photovoltaic Generators with Independent Maximum Power Point Tracking of each Solar Array", IEEE Power Electronics Specialist Conference, pp. 12-43 (2003).

4. S.Busquets-Monge, J. Rocabert, P. Rodriguez, S. Alepuz, J. Bordonau, "Multilevel Diode-clamped Converter for Photovoltaic Generators with Independent Voltage Control of Each Solar Array", IEEE Transactions on Industrial Electronics, vol. 55, p. 2713-2723 (2008).

5. Nandurkar, S.R, Rajeev .M, "Design and Simulation of three phase Inverter for grid connected Photovoltaic systems", Proceedings of Third Biennial National Conference, (NCNTE), pp. 22-33 (2012).

6. Rodriguez J., Lai J.S., Peng F.Z. "Multilevel inverters: A survey of topologies, controls, and applications", IEEE Trans. Ind. Electron., vol. 49, no. 4, pp. 724-738 (2002).

7. Yang, Y. Liu, G. Liu and H. Wang, "Design and Simulation of three phase Inverter for grid connected Photovoltaic systems", IEEE, 11th World Congress on Intelligent Control and Automation (WCICA), pp. 5453 - 5456 (2014).

8. Li.W, Ruan, X. Bao, C.Pan and D.Wang, X. "Grid Synchronization Systems of Three-Phase GridConnected Power Converters: A ComplexVectorFilter Perspective", IEEE Transactions on Industrial
Electronics, Volume 61, Issue: 4, IEEE Industrial Electronics Society, pp. 1855 - 1870 (2014).

9. Muhummad. H. Rashid, "Power Electronics: Circuits, Devices and Applications", Third Edition, Pearson India, pp. 406-428 (2003).

10. Zhilei Yao and Lan Xiao, "Two-Switch Dual-Buck Grid-Connected Inverter with Hysteresis Current Control", IEEE Transactions on Power Electronics, vol. 27, pp. 13-25 (2012).

11. Fang Zheng Peng, Jih-Sheng Lai, and Rodriguez, J. "Multilevel inverters: a survey of topologies, controls, and applications", Industrial Electronics, IEEE Transactions, Vol. 49, pp. 724-738 (2002).

12. Y. Sato, M. Iimura, Y. Dodo, and H. Obara, "A study on minimum required capacitance in flying capacitor multilevel converters for grid connected applications", IEEE Energy Conversion Congress and Exposition (ECCE), pp. 3502-3507 (2015).

13. S. Choi and M. Saeedifard, "Capacitor voltage balancing of flying capacitor multilevel converters by space vector pwm”, vol. 27, pp. 1154-1161 (2012).

14. Srinivas Rao J., Srinivasa Varma, P., Suresh Kumar. $\mathrm{T}$, "Novel switching design structure for three phase 21-level multilevel inverter fed BLDC drive application", International Journal of Power Electronics and Drive Systems, Vol. 9, no.3, pp. 1202-1213 (2018).

15. Holmes, D.G, McGrath, B.P, "Multicarrier PWM strategies for multilevel inverters", Industrial Electronics, IEEE Transactions, Vol. 49, pp. 858- 867 (2002).

16. M. D. Siddique and A. Sarwar, "Performance analysis of carrier based PWM technique for three level diode clamped multilevel inverter with different reference signals" in Proc. IEEE 7th Power India Int. Conf. (PIICON), pp. 1-6 (2016).

17. C. Govindaraju and Dr. K. Baskaran, "Optimized Hybrid Phase Disposition PWM Control Method for Multilevel Inverter", International Journal of Recent Trends in Engineering, vol. 1, pp. 129-134 (2009).

18. E. Babaei, C. Buccella, and M. Saeedifard, "Recent advances in multilevel inverters and their applications", IEEE Trans. Ind. Electron., vol. 63, pp. 7777-7779 (2016). 